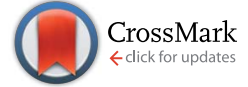

Cite this: Chem. Sci., 2015, 6, 1859

Received 12th October 2014 Accepted 30th November 2014

DOI: $10.1039 / c 4 s c 03128 \mathrm{~h}$

www.rsc.org/chemicalscience

\section{Dehydrogenation, disproportionation and transfer hydrogenation reactions of formic acid catalyzed by molybdenum hydride compounds $\uparrow$}

\begin{abstract}
Michelle C. Neary and Gerard Parkin*
The cyclopentadienyl molybdenum hydride compounds, $\mathrm{Cp}^{\mathrm{R}} \mathrm{Mo}\left(\mathrm{PMe}_{3}\right)_{3-x}(\mathrm{CO})_{x} \mathrm{H}\left(\mathrm{Cp}^{\mathrm{R}}=\mathrm{Cp}, \mathrm{Cp} * ; x=0,1\right.$, 2 or 3), are catalysts for the dehydrogenation of formic acid, with the most active catalysts having the composition $\mathrm{Cp}^{\mathrm{R}} \mathrm{Mo}\left(\mathrm{PMe}_{3}\right)_{2}(\mathrm{CO}) \mathrm{H}$. The mechanism of the catalytic cycle is proposed to involve (i) protonation of the molybdenum hydride complex, (ii) elimination of $\mathrm{H}_{2}$ and coordination of formate, and (iii) decarboxylation of the formate ligand to regenerate the hydride species. NMR spectroscopy indicates that the nature of the resting state depends on the composition of the catalyst. For example, (i) the resting states for the $\mathrm{CpMo}(\mathrm{CO})_{3} \mathrm{H}$ and $\mathrm{CpMo}\left(\mathrm{PMe}_{3}\right)(\mathrm{CO})_{2} \mathrm{H}$ systems are the hydride complexes themselves, (ii) the resting state for the $\mathrm{CpMo}\left(\mathrm{PMe}_{3}\right)_{3} \mathrm{H}$ system is the protonated species $\left[\mathrm{CpMo}\left(\mathrm{PMe}_{3}\right)_{3} \mathrm{H}_{2}\right]^{+}$, and (iii) the resting state for the $\mathrm{CpMo}\left(\mathrm{PMe}_{3}\right)_{2}(\mathrm{CO}) \mathrm{H}$ system is the formate complex, $\mathrm{CpMo}\left(\mathrm{PMe}_{3}\right)_{2}(\mathrm{CO})\left(\kappa^{1}-\mathrm{O}_{2} \mathrm{CH}\right)$, in the presence of a high concentration of formic acid, but $\mathrm{CpMo}\left(\mathrm{PMe}_{3}\right)_{2}(\mathrm{CO}) \mathrm{H}$ when the concentration of acid is low. While $\mathrm{CO}_{2}$ and $\mathrm{H}_{2}$ are the principal products of the catalytic reaction induced by $\mathrm{Cp}^{\mathrm{R}} \mathrm{Mo}\left(\mathrm{PMe}_{3}\right)_{3-x}(\mathrm{CO})_{x} \mathrm{H}$, methanol and methyl formate are also observed. The generation of methanol is a consequence of disproportionation of formic acid, while methyl formate is a product of subsequent esterification. The disproportionation of formic acid is a manifestation of a transfer hydrogenation reaction, which may also be applied to the reduction of aldehydes and ketones. Thus, $\mathrm{CpMo}(\mathrm{CO})_{3} \mathrm{H}$ also catalyzes the reduction of a variety of ketones and aldehydes to alcohols by formic acid, via a mechanism that involves ionic hydrogenation.
\end{abstract}

\section{Introduction}

The growing demand for energy requires the development of alternative energy sources that are more sustainable than fossil fuels and have a reduced impact on the environment. As such, both the sun and the wind are considered to be major candidates for the production of renewable energy. ${ }^{1}$ However, since energy production from these sources would vary with location and time, it is essential to couple the production of energy with efficient methods for storage and transportation. ${ }^{2}$ In this regard, an attractive energy storage medium is provided by hydrogen, ${ }^{3}$ which can, for example, be consumed in a fuel cell with only water as a byproduct. Unfortunately, a problem with using hydrogen in this manner is that present storage and transportation techniques are inadequate. ${ }^{4}$ For example, not only does storing liquid hydrogen present a safety risk, considerable energy is also required to liquefy the hydrogen and maintain it in this form. ${ }^{2 c}$

Department of Chemistry, Columbia University, New York, New York 10027, USA. E-mail: parkin@columbia.edu

$\dagger$ Electronic supplementary information (ESI) available. CCDC 1028432. For ESI and crystallographic data in CIF or other electronic format see DOI: $10.1039 / \mathrm{c} 4 \mathrm{sc} 03128 \mathrm{~h}$
In view of these issues, efforts have focused on the use of physisorption and chemical methods to provide hydrogen on demand..$^{5}$ Of these approaches, the use of formic acid as a chemical medium for storing $\mathrm{H}_{2}$ has garnered much attention. ${ }^{2,6,7}$ Specifically, although formic acid contains only $4.4 \%$ hydrogen by mass, it is an attractive storage medium because (i) it is a liquid at room temperature and is therefore easy to handle and transport, (ii) it is commercially available on a large scale ${ }^{8,9}$ and (iii) the byproduct of $\mathrm{H}_{2}$ release is carbon dioxide which, in principle, can be trapped ${ }^{\mathbf{1 0}}$ and either recycled ${ }^{11,12}$ or used as a $\mathrm{C}_{1}$ source for other chemicals. ${ }^{12}$ With respect to achieving the release of $\mathrm{H}_{2}$ from formic acid, much research has been directed towards the discovery of both heterogeneous $^{13}$ and homogeneous ${ }^{14-22}$ catalyst systems. However, since most of these catalyst systems feature precious metals (e.g. $\mathrm{Pd}, \mathrm{Pt}, \mathrm{Au}$ ), an important current thrust is the discovery of catalysts that utilize earth abundant nonprecious metals. ${ }^{19-22}$ Therefore, we report here a series of molybdenum compounds that are not only effective for the catalytic release of $\mathrm{H}_{2}$ from formic acid, but are also capable of (i) forming methanol via disproportionation of formic acid and (ii) using formic acid as a reagent for the transfer hydrogenation of aldehydes and ketones. 


\section{Results and discussion}

We have previously described the first example of a molybdenum compound, namely $\mathrm{Cp} * \mathrm{Mo}\left(\mathrm{PMe}_{3}\right)_{2}(\mathrm{CO}) \mathrm{H},{ }^{20,23}$ to serve as a catalyst for the dehydrogenation (decarboxylation) of formic acid (Scheme 1). ${ }^{24}$ In order to understand the factors that influence dehydrogenation, we sought to extend the investigation to the series of compounds, $\mathrm{CpMo}\left(\mathrm{PMe}_{3}\right)_{3-x}(\mathrm{CO})_{x} \mathrm{H}$ and $\mathrm{Cp} * \mathrm{Mo}\left(\mathrm{PMe}_{3}\right)_{3-x}(\mathrm{CO})_{x} \mathrm{H}(x=0,1,2$ or 3$)$, in which the substitution of (i) $\mathrm{PMe}_{3}$ ligands by $\mathrm{CO}$ and (ii) $\mathrm{Cp} *$ ligands by $\mathrm{Cp}$ would be expected to exert significant electronic and structural effects, as illustrated by the fact that the oxidation potentials of the $\mathrm{CpMo}\left(\mathrm{PMe}_{3}\right)_{3-x}(\mathrm{CO})_{x} \mathrm{H} /\left[\mathrm{CpMo}\left(\mathrm{PMe}_{3}\right)_{3-x}(\mathrm{CO})_{x} \mathrm{H}\right]^{+}$couples span a range of $c a .2 \mathrm{~V}^{25}$

Indeed, comparison of $\mathrm{CpMo}\left(\mathrm{PMe}_{3}\right)_{3} \mathrm{H},{ }^{26} \mathrm{CpMo}\left(\mathrm{PMe}_{3}\right)_{2}(\mathrm{CO}) \mathrm{H},{ }^{27}$ $\mathrm{CpMo}\left(\mathrm{PMe}_{3}\right)(\mathrm{CO})_{2} \mathrm{H}^{27,28}$ and $\mathrm{CpMo}(\mathrm{CO})_{3} \mathrm{H}^{29}$ indicates that substitution of a CO ligand by $\mathrm{PMe}_{3}$ has a profound effect on the rate of decarboxylation and release of $\mathrm{H}_{2}$ (Table 1). ${ }^{30}$ For example, while the reaction catalyzed by the tricarbonyl derivative, $\mathrm{CpMo}(\mathrm{CO})_{3} \mathrm{H}$, requires temperatures of $100{ }^{\circ} \mathrm{C}$ in order to proceed efficiently in benzene, the bis(phosphine) derivative, $\mathrm{CpMo}\left(\mathrm{PMe}_{3}\right)_{2}(\mathrm{CO}) \mathrm{H}$, is an effective catalyst at room temperature. ${ }^{31}$ Most interestingly, the trend is not monotonic, such that the tris(phosphine) derivative $\mathrm{CpMo}\left(\mathrm{PMe}_{3}\right)_{3} \mathrm{H}$ exhibits no significant catalytic activity at room temperature. Thus, of the series of compounds $\mathrm{CpMo}\left(\mathrm{PMe}_{3}\right)_{3-x}(\mathrm{CO})_{x} \mathrm{H}$, the bis(phosphine) derivative, $\mathrm{CpMo}\left(\mathrm{PMe}_{3}\right)_{2}(\mathrm{CO}) \mathrm{H}$, has the greatest activity.

Although $\mathrm{CpMo}\left(\mathrm{PMe}_{3}\right)_{3} \mathrm{H}$ exhibits little activity at room temperature, it does, nevertheless, induce the decarboxylation of formic acid at elevated temperatures. However, it is evident that $\mathrm{CpMo}\left(\mathrm{PMe}_{3}\right)_{3} \mathrm{H}$ is not necessarily the catalytically active species because it is converted to the monocarbonyl compound $\mathrm{CpMo}\left(\mathrm{PMe}_{3}\right)_{2}(\mathrm{CO}) \mathrm{H}$ under these conditions (Scheme 2). ${ }^{32}$

The nature of the substituents on the cyclopentadienyl ring also influences the reactivity, with $\mathrm{Cp} * \mathrm{Mo}\left(\mathrm{PMe}_{3}\right)_{2}(\mathrm{CO}) \mathrm{H}$ being a more active catalyst than $\mathrm{CpMo}\left(\mathrm{PMe}_{3}\right)_{2}(\mathrm{CO}) \mathrm{H}$ (Table 1). ${ }^{31}$ The difference is not, however, as pronounced as that achieved by variation of the number of $\mathrm{PMe}_{3}$ and $\mathrm{CO}$ ligands.

The essential features of the mechanism proposed for the catalytic cycle are illustrated in Scheme 3 and involve two main sequences, namely (i) protonation, elimination of $\mathrm{H}_{2}$ and coordination of formate, and (ii) decarboxylation of the formate ligand to regenerate the hydride species. In order to obtain evidence for such a mechanism, the nature of the molybdenumcontaining compounds that form upon treatment of

$$
\begin{gathered}
\text { dehydrogenation } \\
\mathrm{HCO}_{2} \mathrm{H} \longrightarrow \mathrm{CO}_{2}+\mathrm{H}_{2}
\end{gathered}
$$

\section{disproportionation}

$$
3 \mathrm{HCO}_{2} \mathrm{H} \longrightarrow \mathrm{CH}_{3} \mathrm{OH}+2 \mathrm{CO}_{2}+\mathrm{H}_{2} \mathrm{O}
$$

Scheme 1 Dehydrogenation and disproportionation of $\mathrm{HCO}_{2} \mathrm{H}$.
Table 1 Turnover frequencies $\left(\mathrm{h}^{-1}\right)$ for dehydrogenation of formic acid by $\mathrm{Cp}^{\mathrm{R}} \mathrm{Mo}\left(\mathrm{PMe}_{3}\right)_{3-x}(\mathrm{CO})_{x} \mathrm{H}$ at $100{ }^{\circ} \mathrm{C}^{a}$

\begin{tabular}{lll}
\hline & $\mathrm{Cp}$ & $\mathrm{Cp}$ \\
\hline $\mathrm{Cp}^{\mathrm{R}} \mathrm{Mo}\left(\mathrm{PMe}_{3}\right)_{2}(\mathrm{CO}) \mathrm{H}$ & 31 & 54 \\
$\mathrm{Cp}^{\mathrm{R}} \mathrm{Mo}\left(\mathrm{PMe}_{3}\right)(\mathrm{CO})_{2} \mathrm{H}$ & 0.64 & 1.2 \\
$\mathrm{Cp}^{\mathrm{R}} \mathrm{Mo}(\mathrm{CO})_{3} \mathrm{H}$ & 0.67 & 0.33
\end{tabular}

${ }^{a}\left[\mathrm{Cp}^{\mathrm{R}} \mathrm{Mo}\left(\mathrm{PMe}_{3}\right)_{3-x}(\mathrm{CO})_{x} \mathrm{H}\right]=0.016 \mathrm{M},\left[\mathrm{HCO}_{2} \mathrm{H}\right]_{\text {initial }}=0.39 \mathrm{M}, \mathrm{C}_{6} \mathrm{D}_{6}$, values at $50 \%$ conversion.

$\mathrm{CpMo}\left(\mathrm{PMe}_{3}\right)_{3-x}(\mathrm{CO})_{x} \mathrm{H}(x=0,1,2$, or 3$)$ with formic acid has been probed by NMR spectroscopy.

Evidence that $\mathrm{CpMo}\left(\mathrm{PMe}_{3}\right)_{3-x}(\mathrm{CO})_{x} \mathrm{H}$ may be protonated by formic acid is provided by the observation that treatment of $\mathrm{CpMo}\left(\mathrm{PMe}_{3}\right)_{3} \mathrm{H}$ with formic acid results in the formation of $\left[\mathrm{CpMo}\left(\mathrm{PMe}_{3}\right)_{3} \mathrm{H}_{2}\right]\left[\mathrm{HCO}_{2}\right]$, which is characterized by two hydride signals in a $1: 1$ ratio at $-2.57\left[\mathrm{~m},{ }^{2} J_{\mathrm{P}-\mathrm{H}}=54,{ }^{2} J_{\mathrm{P}-\mathrm{H}}=49\right.$ and $\left.{ }^{2} J_{\mathrm{H}-\mathrm{H}}=8\right]$ and $-5.74\left[\mathrm{~m},{ }^{2} J_{\mathrm{P}-\mathrm{H}}=46,{ }^{2} J_{\mathrm{P}-\mathrm{H}}=8\right.$ and $\left.{ }^{2} J_{\mathrm{H}-\mathrm{H}}=8\right]$ in the ${ }^{1} \mathrm{H}$ NMR spectrum $\left(\mathrm{CD}_{3} \mathrm{CN}\right)$ at $239 \mathrm{~K}^{33}$ Support for the identification of $\left[\mathrm{CpMo}\left(\mathrm{PMe}_{3}\right)_{3} \mathrm{H}_{2}\right]\left[\mathrm{HCO}_{2}\right]$ is provided by previous studies in which $\left[\mathrm{CpMo}\left(\mathrm{PMe}_{3}\right)_{3} \mathrm{H}_{2}\right]^{+}$has been generated by the reaction of $\mathrm{CpMo}\left(\mathrm{PMe}_{3}\right)_{3} \mathrm{H}$ with $\mathrm{HBF}_{4} \cdot{ }^{25,26 a}$

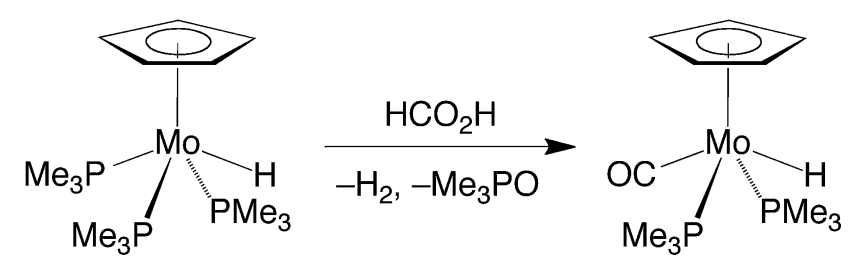

Scheme 2 Conversion of $\mathrm{CpMo}\left(\mathrm{PMe}_{3}\right)_{3} \mathrm{H}$ to $\mathrm{CpMo}\left(\mathrm{PMe}_{3}\right)_{2}(\mathrm{CO}) \mathrm{H}$ by formic acid.

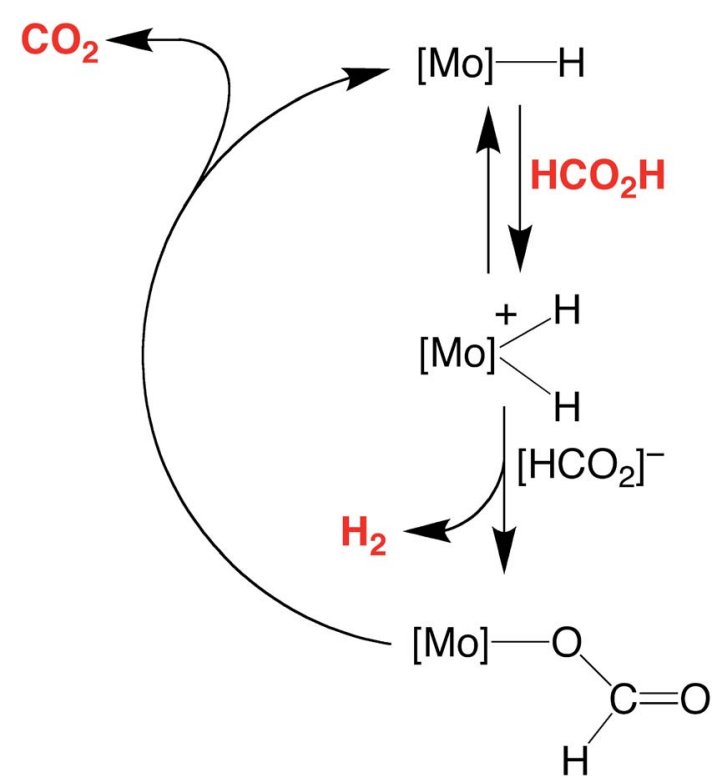

Scheme 3 Essential features for the proposed mechanism of dehydrogenation of $\mathrm{HCO}_{2} \mathrm{H}$ by $\mathrm{Cp}^{\mathrm{R}} \mathrm{Mo}\left(\mathrm{PMe}_{3}\right)_{3-x}(\mathrm{CO})_{x} \mathrm{H}$. 


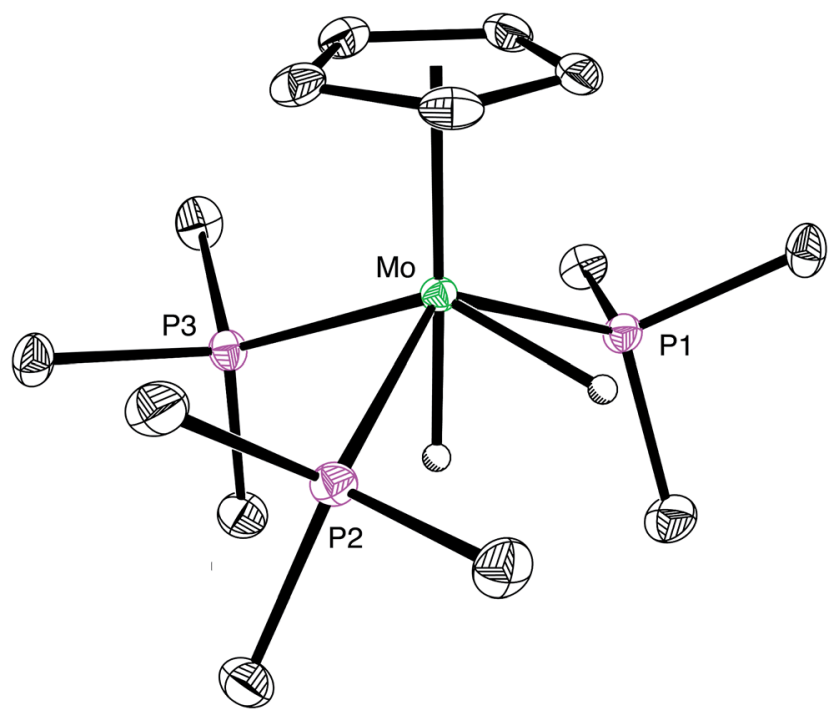

Fig. 1 Molecular structure of $\left[\mathrm{CpMo}\left(\mathrm{PMe}_{3}\right)_{3} \mathrm{H}_{2}\right][\mathrm{Cl}$ (only the cation is shown).

Furthermore, we have also structurally characterized the chloride derivative $\left[\mathrm{CpMo}\left(\mathrm{PMe}_{3}\right)_{3} \mathrm{H}_{2}\right][\mathrm{Cl}]$ by X-ray diffraction (Fig. 1), which reinforces its identification as a dihydride rather than a dihydrogen complex. ${ }^{34}$

However, despite the fact that $\mathrm{CpMo}\left(\mathrm{PMe}_{3}\right)_{3} \mathrm{H}$ is readily protonated, it is not, as noted above, an effective catalyst for decarboxylation of formic acid at room temperature. Presumably, the catalytic inactivity of $\mathrm{CpMo}\left(\mathrm{PMe}_{3}\right)_{3} \mathrm{H}$ is a consequence of dissociation of $\mathrm{H}_{2}$ from $\left[\mathrm{CpMo}\left(\mathrm{PMe}_{3}\right)_{3} \mathrm{H}_{2}\right]\left[\mathrm{HCO}_{2}\right]$ being nonfacile at room temperature. Supporting this suggestion, the tetrafluoroborate derivative, $\left[\mathrm{CpMo}\left(\mathrm{PMe}_{3}\right)_{3} \mathrm{H}_{2}\right]\left[\mathrm{BF}_{4}\right]$, is stable with respect to dissociation of $\mathrm{H}_{2}$ at $80{ }^{\circ} \mathrm{C} .{ }^{25}$

Evidence for the formation of a protonated species has also been obtained for the reaction of $\mathrm{CpMo}\left(\mathrm{PMe}_{3}\right)_{2}(\mathrm{CO}) \mathrm{H}$ with formic acid. Specifically, treatment of $\mathrm{CpMo}\left(\mathrm{PMe}_{3}\right)_{2}(\mathrm{CO}) \mathrm{H}$ in $d_{8}$-toluene with an excess of formic acid at low temperature (276 $\mathrm{K})$ allows for observation of a protonated species, $\left[\mathrm{CpMo}\left(\mathrm{PMe}_{3}\right)_{2}(\mathrm{CO}) \mathrm{H}_{2}\right]^{+}$, which is characterized by a triplet signal assignable to the hydride ligands at $-3.33 \mathrm{ppm}\left[\mathrm{t},{ }^{2} J_{\mathrm{P}-\mathrm{H}}=\right.$ $43 \mathrm{~Hz}]$ in the ${ }^{1} \mathrm{H}$ NMR spectrum. ${ }^{35,36}$ In contrast to $\left[\mathrm{CpMo}\left(\mathrm{PMe}_{3}\right)_{3} \mathrm{H}_{2}\right]^{+}$, however, $\left[\mathrm{CpMo}\left(\mathrm{PMe}_{3}\right)_{2}(\mathrm{CO}) \mathrm{H}_{2}\right]^{+}$does not persist at room temperature, dissociating $\mathrm{H}_{2}$ and coordinating formate to give $\mathrm{CpMo}\left(\mathrm{PMe}_{3}\right)_{2}(\mathrm{CO})\left(\kappa^{1}-\mathrm{O}_{2} \mathrm{CH}\right)$. The latter compound is also unstable and only exists for a prolonged period in the presence of excess formic acid because it slowly dissociates $\mathrm{CO}_{2}$ and regenerates $\mathrm{CpMo}\left(\mathrm{PMe}_{3}\right)_{2}(\mathrm{CO}) \mathrm{H}^{37}$ It is, therefore, evident that both protonation and release of $\mathrm{H}_{2}$ is facile in this system, such that decarboxylation is the turnoverlimiting step of the catalytic cycle in benzene during the initial stages. However, as the formic acid is consumed, the pseudo first order rate constant for protonation of $\mathrm{CpMo}\left(\mathrm{PMe}_{3}\right)_{2}(\mathrm{CO}) \mathrm{H}$ decreases relative to that for decarboxylation of $\mathrm{CpMo}\left(\mathrm{PMe}_{3}\right)_{2}(\mathrm{CO})\left(\kappa^{1}-\mathrm{O}_{2} \mathrm{CH}\right)$, such that $\mathrm{CpMo}\left(\mathrm{PMe}_{3}\right)_{2}(\mathrm{CO}) \mathrm{H}$ becomes the resting state during the latter stage of the catalytic transformation.
Unlike $\mathrm{CpMo}\left(\mathrm{PMe}_{3}\right)_{3} \mathrm{H}$ and $\mathrm{CpMo}\left(\mathrm{PMe}_{3}\right)_{2}(\mathrm{CO}) \mathrm{H}$, the dicarbonyl and tricarbonyl compounds, $\mathrm{CpMo}\left(\mathrm{PMe}_{3}\right)(\mathrm{CO})_{2} \mathrm{H}$ and $\mathrm{CpMo}(\mathrm{CO})_{3} \mathrm{H}$, do not react with formic acid in benzene at room temperature. As such, elevated temperatures are required for efficient catalysis. However, although it is unreactive towards formic acid at room temperature, previous studies have shown that $\mathrm{CpMo}\left(\mathrm{PMe}_{3}\right)(\mathrm{CO})_{2} \mathrm{H}$ reacts with a stronger acid, namely $\mathrm{HBF}_{4}$, to release $\mathrm{H}_{2}$, with no observation of the dihydride cation, $\left[\mathrm{CpMo}\left(\mathrm{PMe}_{3}\right)(\mathrm{CO})_{2} \mathrm{H}_{2}\right]^{+} .^{38,39}$ Likewise, $\mathrm{CpMo}(\mathrm{CO})_{3} \mathrm{H}$ rapidly eliminates $\mathrm{H}_{2}$ upon treatment with $\mathrm{TfOH}$ to afford $\mathrm{CpMo}(\mathrm{CO})_{3} \mathrm{OTf}$, with no observation of $\left[\mathrm{CpMo}(\mathrm{CO})_{3} \mathrm{H}_{2}\right]^{+}{ }^{39 a, 40}$ On the basis of these observations, it is evident that the reduced basicity of the metal center resulting from the increased replacement of the $\mathrm{PMe}_{3}$ ligands by $\mathrm{CO}^{41,42}$ causes protonation to be turnover-limiting.

The above observations clearly indicate that, for the series of $\mathrm{CpMo}\left(\mathrm{PMe}_{3}\right)_{3-x}(\mathrm{CO})_{x} \mathrm{H}$ compounds, the turnover-limiting step depends on the distribution of $\mathrm{PMe}_{3}$ and $\mathrm{CO}$ ligands. Specifically, (i) the catalytic activities of $\mathrm{CpMo}(\mathrm{CO})_{3} \mathrm{H}$ and $\mathrm{CpMo}\left(\mathrm{PMe}_{3}\right)(\mathrm{CO})_{2} \mathrm{H}$ are limited by their susceptibility to protonation by formic acid, (ii) the activity of $\mathrm{CpMo}\left(\mathrm{PMe}_{3}\right)_{3} \mathrm{H}$ is limited by the inability of $\left[\mathrm{CpMo}\left(\mathrm{PMe}_{3}\right)_{3} \mathrm{H}_{2}\right]^{+}$to dissociate $\mathrm{H}_{2}$, and (iii) the activity of $\mathrm{CpMo}\left(\mathrm{PMe}_{3}\right)_{2}(\mathrm{CO}) \mathrm{H}$ is limited by decarboxylation of the formate intermediate, $\mathrm{CpMo}\left(\mathrm{PMe}_{3}\right)_{2}(\mathrm{CO})\left(\kappa^{1}-\mathrm{O}_{2} \mathrm{CH}\right)$, in the presence of a high concentration of formic acid, but by protonation of $\mathrm{CpMo}\left(\mathrm{PMe}_{3}\right)_{2}(\mathrm{CO}) \mathrm{H}$ when the concentration of acid is low.

The different forms of the catalyst resting states provide some insight into the non-monotonic variation in activity upon substituting $\mathrm{PMe}_{3}$ for carbonyl ligands. Thus, while $\mathrm{CpMo}(\mathrm{CO})_{3} \mathrm{H}$ has a low activity because the metal center is not susceptible to protonation, $\mathrm{CpMo}\left(\mathrm{PMe}_{3}\right)_{3} \mathrm{H}$ has a low activity because the protonated derivative $\left[\mathrm{CpMo}\left(\mathrm{PMe}_{3}\right)_{3} \mathrm{H}_{2}\right]^{+}$is relatively stable with respect to elimination of $\mathrm{H}_{2}$. As such, the hybrid carbonyl/phosphine derivatives, $\mathrm{Cp}^{\mathrm{R}} \mathrm{Mo}\left(\mathrm{PMe}_{3}\right)_{2}(\mathrm{CO}) \mathrm{H}$, have the greatest reactivity.

Interestingly, while $\mathrm{CO}_{2}$ and $\mathrm{H}_{2}$ are the principal products of the catalytic conversion of formic acid by $\mathrm{Cp}^{\mathrm{R}} \mathrm{Mo}\left(\mathrm{PMe}_{3}\right)_{3-x}(\mathrm{CO})_{x} \mathrm{H}(\mathrm{R}=\mathrm{H}, \mathrm{Me})$, methanol and methyl formate are also observed. The formation of methanol is a consequence of disproportionation of formic acid (Scheme 1), while the methyl formate is a result of subsequent esterification. The observation of this additional pathway is of note in view of the fact that the generation of methanol is a key component of the potential methanol economy, ${ }^{43}$ and yet there are only two reports for the formation of methanol by the homogeneous catalytic disproportionation of formic acid. ${ }^{15 g, 17 c, 44}$ Furthermore, both of these reports describe catalysts that contain precious metals, namely iridium ${ }^{17 c}$ and ruthenium. ${ }^{15 g}$ As such, the ability to catalyze this transformation by compounds containing the nonprecious metal, molybdenum, is noteworthy. The selectivity for the catalytic formation of methanol and methyl formate relative to decarboxylation by $\mathrm{Cp}^{\mathrm{R}} \mathrm{Mo}\left(\mathrm{PMe}_{3}\right)_{3-x}(\mathrm{CO})_{x} \mathrm{H}$ depends on the nature of the cyclopentadienyl substituents and the number of carbonyl ligands, and is greatest for $\mathrm{CpMo}(\mathrm{CO})_{3} \mathrm{H}$, which can achieve a selectivity $^{45}(21 \%)$ that is intermediate between the values for the iridium $(12 \%)^{17 c}$ and ruthenium $(27 \%)^{15 g, 46}$ systems. 
A simplified mechanism for the formation of methanol is illustrated in Scheme 4 and is based on that previously proposed for the catalytic ionic hydrogenation of ketones..$^{34,39,47-49}$ Thus, it is proposed that $\mathrm{Cp}^{\mathrm{R}} \mathrm{Mo}\left(\mathrm{PMe}_{3}\right)_{3-x}(\mathrm{CO})_{x} \mathrm{H}$ delivers a hydride ligand to the protonated form of formic acid, $\left[\mathrm{HC}(\mathrm{OH})_{2}\right]^{+}$, which is present due to autoionization ${ }^{50}$ or generated incipiently, thereby forming methylene diol. The formation of methanol from $\mathrm{CH}_{2}(\mathrm{OH})_{2}$ can be achieved in principle by either (i) disproportionation to methanol and formic acid, ${ }^{51}$ or by (ii) dehydration to formaldehyde followed by catalytic ionic hydrogenation akin to that for the first reduction sequence of formic acid (Scheme 4).

Support for a direct proton and hydride transfer, rather than reaction with the $\mathrm{H}_{2}$ released via decarboxylation, is provided by the observation that performing the reaction under $\mathrm{D}_{2}(1 \mathrm{~atm})$ results in no deuterium incorporation into the methanol or methyl formate.

On the basis of the mechanisms illustrated in Scheme 3 and scheme 4 for the dehydrogenation and disproportionation of formic acid, the relative selectivity of the two processes (dehydrogenation versus disproportionation) is influenced by the preference of the metal center to transfer a hydride ligand to $\left[\mathrm{HC}(\mathrm{OH})_{2}\right]^{+}$(which is present in low concentration) relative to its tendency to undergo protonation and liberate $\mathrm{H}_{2}$ (Scheme 5). As such, the $\mathrm{p} K_{\mathrm{B}}$ and the hydricity of $\mathrm{Cp}^{\mathrm{R}} \mathrm{Mo}\left(\mathrm{PMe}_{3}\right)_{3-x}(\mathrm{CO})_{x} \mathrm{H}$ are expected to play an important role in influencing the selectivity. In this regard, while such values have been reported for a variety of metal hydride derivatives, ${ }^{41,52-54}$ data for all the compounds described here are not available. Nevertheless, the kinetic hydricity of $\mathrm{CpMo}\left(\mathrm{PMe}_{3}\right)(\mathrm{CO})_{2} \mathrm{H}$ is significantly greater than that of $\mathrm{CpMo}(\mathrm{CO})_{3} \mathrm{H}$, by a factor of $c a .10^{4},{ }^{52}$ which is in accord with the notion that replacing a $\mathrm{CO}$ ligand by $\mathrm{PMe}_{3}$ would be expected to promote dissociation of hydride. ${ }^{55}$ However, it is also generally recognized that the basicity of a metal center increases upon replacing a CO ligand by $\mathrm{PR}_{3}$ (vide supra), ${ }^{41,42}$ and so it is nontrivial to predict $a$ priori the relative influence of such substitution on the two pathways.

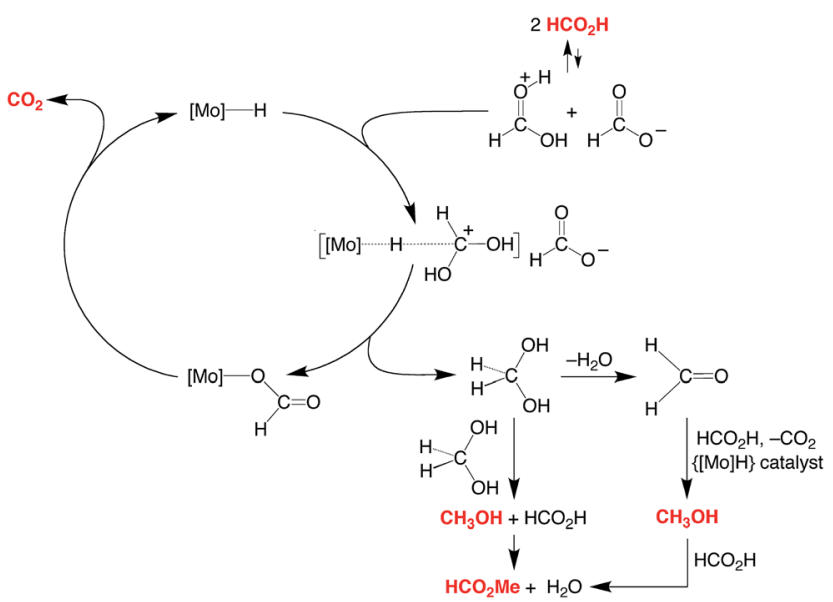

Scheme 4 Essential features for the proposed mechanism of disproportionation of $\mathrm{HCO}_{2} \mathrm{H}$ by $\mathrm{Cp}^{\mathrm{R}} \mathrm{Mo}\left(\mathrm{PMe}_{3}\right)_{3-x}(\mathrm{CO})_{x} \mathrm{H}$.

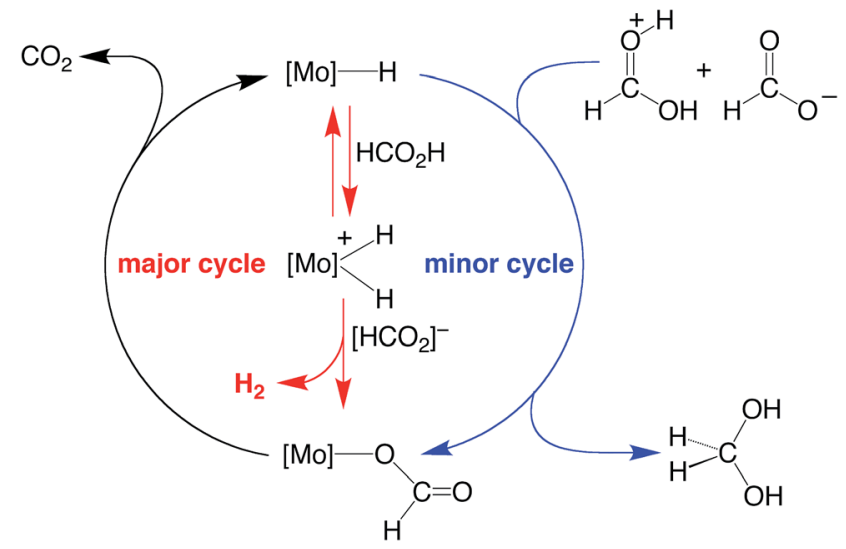

Scheme 5 Possible origin of the selectivity of disproportionation versus dehydrogenation of formic acid.

The ability of these molybdenum compounds to catalyze the disproportionation of formic acid prompted the possibility that a system could be developed to use formic acid as a reagent in the transfer hydrogenation of other substrates. In this regard, transfer hydrogenation, ${ }^{56,57}$ often employing isopropanol as the reductant, offers considerable advantages over direct reduction by hydrogen because it obviates the need to use $\mathrm{H}_{2}{ }^{56}$ However, disadvantages of using isopropanol are that (i) isopropanol is obtained commercially by the hydration of propene, ${ }^{58}$ and (ii) the reactions are often reversible, such that the isopropanol needs to be used as a solvent to drive the equilibrium. ${ }^{56}$ In contrast, formic acid is available from renewable sources, and the release of $\mathrm{CO}_{2}$ as a byproduct renders the reaction effectively irreversible.$^{56}$ However, catalysts that are commonly used to effect transfer hydrogenation using formic acid are largely restricted to the platinum group metals, namely $\mathrm{Ru}, \mathrm{Rh}, \mathrm{Pd}$ and Ir,${ }^{59-61}$ with few reports employing other metals, ${ }^{62}$ and none employing Mo. It is, therefore, noteworthy that $\mathrm{CpMo}(\mathrm{CO})_{3} \mathrm{H}$ is also capable of effecting transfer hydrogenation of a variety of

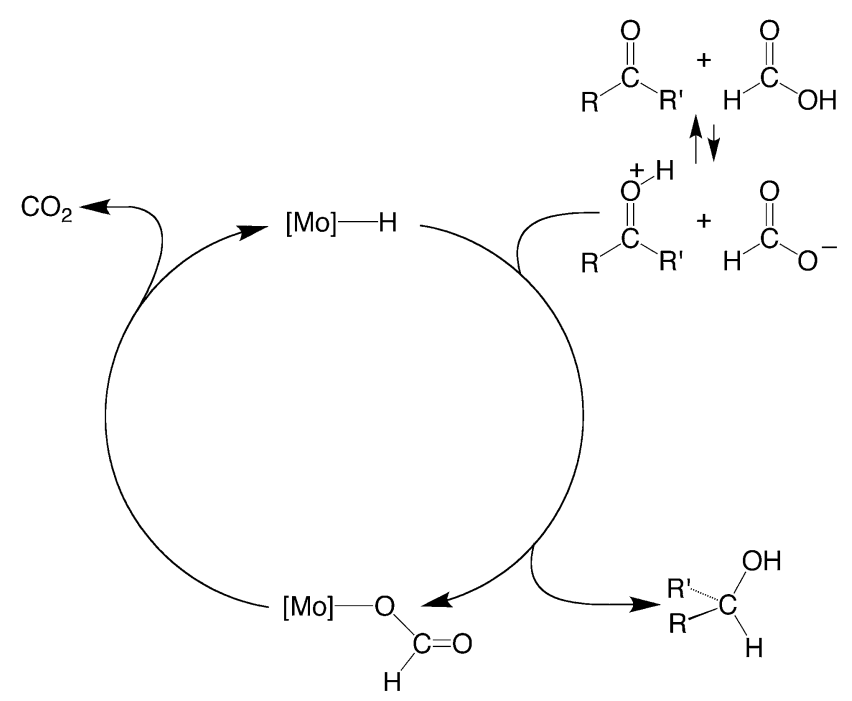

Scheme 6 lonic hydrogenation of carbonyl compounds. 
carbonyl compounds, namely RCHO $\left(\mathrm{R}=\mathrm{Me}, \mathrm{Pr}^{\mathrm{i}}\right), \mathrm{RC}(\mathrm{O}) \mathrm{Me}$ $\left(\mathrm{R}=\mathrm{Me}, \mathrm{Pr}^{\mathrm{i}}, \mathrm{Bu}^{\mathrm{t}}, \mathrm{Ph}\right)$ and $\mathrm{Ph}_{2} \mathrm{CO}$, using formic acid as the reductant, ${ }^{63}$ as illustrated in Scheme 6. For example, $\mathrm{Ph}_{2} \mathrm{CO}$ is reduced by $\mathrm{HCO}_{2} \mathrm{H}$ to $\mathrm{Ph}_{2} \mathrm{CH}(\mathrm{OH})$ with a selectivity of $29 \%$ relative to decarboxylation and disproportionation, while $\mathrm{Pr}^{\mathrm{i}} \mathrm{CHO}$ is reduced to $\mathrm{Bu}^{\mathrm{i}} \mathrm{OH}$ and $\mathrm{HCO}_{2} \mathrm{Bu}^{\mathrm{i}}(3: 1)$ with a selectivity of $32 \% .{ }^{64-67}$

\section{Conclusions}

In summary, the cyclopentadienyl molybdenum hydride compounds, $\mathrm{Cp}^{\mathrm{R}} \mathrm{Mo}\left(\mathrm{PMe}_{3}\right)_{3-x}(\mathrm{CO})_{x} \mathrm{H}\left(\mathrm{Cp}^{\mathrm{R}}=\mathrm{Cp}, \mathrm{Cp}^{*} ; x=0,1,2\right.$ or 3$)$, are catalysts for the dehydrogenation of formic acid. The activity of these catalysts is not a monotonic function of the number of $\mathrm{CO}$ or $\mathrm{PMe}_{3}$ ligands and is greatest for $\mathrm{Cp}^{\mathrm{R}} \mathrm{Mo}\left(\mathrm{PMe}_{3}\right)_{2}(\mathrm{CO}) \mathrm{H}$. Specifically, while $\mathrm{CpMo}(\mathrm{CO})_{3} \mathrm{H}$ has a low activity because the metal center is not susceptible towards protonation, $\mathrm{CpMo}\left(\mathrm{PMe}_{3}\right)_{3} \mathrm{H}$ has a low activity because the protonated derivative $\left[\mathrm{CpMo}\left(\mathrm{PMe}_{3}\right)_{3} \mathrm{H}_{2}\right]^{+}$is relatively stable with respect to elimination of $\mathrm{H}_{2}$. As such, the hybrid carbonyl/ phosphine derivatives, $\mathrm{Cp}^{\mathrm{R}} \mathrm{Mo}\left(\mathrm{PMe}_{3}\right)_{2}(\mathrm{CO}) \mathrm{H}$, have the greatest reactivity. In addition to catalyzing the dehydrogenation of formic acid, $\mathrm{Cp}^{\mathrm{R}} \mathrm{Mo}\left(\mathrm{PMe}_{3}\right)_{3-x}(\mathrm{CO})_{x} \mathrm{H}$ also catalyzes its disproportionation to methanol and $\mathrm{CO}_{2}$ via a transfer hydrogenation reaction. Similarly, $\mathrm{CpMo}(\mathrm{CO})_{3} \mathrm{H}$ also catalyzes the reduction of aldehydes and ketones by formic acid via a mechanism that involves ionic hydrogenation. These investigations demonstrate that molybdenum hydride compounds have much potential with respect to transfer hydrogenation reactions involving formic acid.

\section{Acknowledgements}

We thank the US Department of Energy, Office of Basic Energy Sciences (DE-FG02-93ER14339) for support of this research. M. C. N. acknowledges the National Science Foundation for a Graduate Research Fellowship under Grant no. DGE 11-44155. Dr Deven P. Estes and Jonathan L. Kuo are thanked for technical assistance with high pressure experiments.

\section{Notes and references}

1 M. Z. Jacobson, Energy Environ. Sci., 2009, 2, 148-173.

2 (a) M. Grasemann and G. Laurenczy, Energy Environ. Sci., 2012, 5, 8171-8181; (b) S. Enthaler, J. von Langermann and T. Schmidt, Energy Environ. Sci., 2010, 3, 1207-1217; (c) S. Enthaler, ChemSusChem, 2008, 1, 801-804; (d) F. Joó, ChemSusChem, 2008, 1, 805-808.

3 S. Satyapal, J. Petrovic, C. Read, G. Thomas and G. Ordaz, Catal. Today, 2007, 120, 246-256.

4 L. Schlapbach and A. Züttel, Nature, 2001, 414, 353-358.

5 U. Eberle, M. Felderhoff and F. Schüth, Angew. Chem., Int. Ed., 2009, 48, 6608-6630.

6 W.-H. Wang, Y. Himeda, J. T. Muckerman and E. Fujita, Adv. Inorg. Chem., 2014, 66, 189-222.
7 (a) B. Loges, A. Boddien, F. Gärtner, H. Junge and M. Beller, Top. Catal., 2010, 53, 902-914; (b) G. Laurenczy, Chimia, 2011, 65, 663-666.

8 For example, formic acid can be obtained from methyl formate and synthesis gas. See: (a) W. Reutemann and H. Kieczka, Ullmann's Encyclopedia of Industrial Chemistry, 2011, pp. 13-33; (b) I. Wender, Annu. Rev. Energy, 1986, 11, 295-314.

9 The synthesis of formic acid from biomass has also emerged as another promising source. See: A. Kruse and A. Gawlik, Ind. Eng. Chem. Res., 2003, 42, 267-279.

10 K. Sumida, D. L. Rogow, J. A. Mason, T. M. McDonald, E. D. Bloch, Z. R. Herm, T.-H. Bae and J. R. Long, Chem. Rev., 2012, 112, 724-781.

11 A. Behr and K. Nowakowski, Adv. Inorg. Chem., 2014, 66, 223258.

12 (a) M. Peters, B. Köhler, W. Kuckshinrichs, W. Leitner, P. Markewitz and T. E. Müller, ChemSusChem, 2011, 4, 1216-1240; (b) M. He, Y. Sun and B. Han, Angew. Chem., Int. Ed., 2013, 52, 9620-9633; (c) A. M. Appel, J. E. Bercaw, A. B. Bocarsly, H. Dobbek, D. L. Dubois, M. Dupuis, J. G. Ferry, E. Fujita, R. Hille, P. J. A. Kenis, C. A. Kerfeld, R. H. Morris, C. H. F. Peden, A. R. Portis, S. W. Ragsdale, T. B. Rauchfuss, J. N. H. Reek, L. C. Seefeldt, R. K. Thauer and G. L. Waldrop, Chem. Rev., 2013, 113, 6621-6658.

13 S.-W. Ting, C. Hu, J. K. Pulleri and K.-Y. Chan, Ind. Eng. Chem. Res., 2012, 51, 4861-4867 and references therein.

14 M. Vogt, A. Nerush, Y. Diskin-Posner, Y. Ben-David and D. Milstein, Chem. Sci., 2014, 5, 2043-2051.

15 (a) R. S. Coffey, Chem. Commun., 1967, 923-924; (b) Y. Gao, J. Kuncheria, G. P. A. Yap and R. J. Puddephatt, Chem. Commun., 1998, 2365-2366; (c) M. L. Man, Z. Zhou, S. M. Ng and C. P. Lau, Dalton Trans., 2003, 2, 3727-3735; (d) A. Boddien, B. Loges, H. Junge and M. Beller, ChemSusChem, 2008, 1, 751-758; (e) C. Fellay, N. Yan, P. J. Dyson and G. Laurenczy, Chem. Eur. J., 2009, 15, 3752-3760; (f) S. Fukuzumi, T. Kobayashi and T. Suenobu, J. Am. Chem. Soc., 2010, 132, 1496-1497; $(g)$ S. Savourey, G. Lefèvre, J.-C. Berthet, P. Thuéry, C. Genre and T. Cantat, Angew. Chem., Int. Ed., 2014, 53, 10466-10470.

16 S. Fukuzumi, T. Kobayashi and T. Suenobu, ChemSusChem, 2008, 1, 827-834.

17 (a) Y. Himeda, Green Chem., 2009, 11, 2018-2022; (b) Y. Maenaka, T. Suenobu and S. Fukuzumi, Energy Environ. Sci., 2012, 5, 7360-7367; (c) A. J. M. Miller, D. M. Heinekey, J. M. Mayer and K. I. Goldberg, Angew. Chem., Int. Ed., 2013, 52, 3981-3984; (d) Y. Manaka, W.-H. Wang, Y. Suna, H. Kambayashi, J. T. Muckerman, E. Fujita and Y. Himeda, Catal. Sci. Technol., 2014, 4, 34-37.

18 J. Broggi, V. Jurčík, O. Songis, A. Poater, L. Cavallo, A. M. Z. Slawin and C. S. J. Cazin, J. Am. Chem. Soc., 2013, 135, 4588-4591.

19 (a) C. Bianchini, M. Peruzzini, A. Polo, A. Vacca and F. Zanobini, Gazz. Chim. Ital., 1991, 121, 543-549; (b) A. Boddien, D. Mellmann, F. Gärtner, R. Jackstell, H. Junge, P. J. Dyson, G. Laurenczy, R. Ludwig and M. Beller, Science., 2011, 333, 1733-1736; (c) T. Zell, 
B. Butschke, Y. Ben-David and D. Milstein, Chem. Eur. J., 2013， 19，8068-8072; (d) C. Federsel, A. Boddien, R. Jackstell, R. Jennerjahn, P. J. Dyson, R. Scopelliti, G. Laurenczy and M. Beller, Angew. Chem., Int. Ed., 2010, 49, 9777-9780; (e) A. Boddien, B. Loges, F. Gärtner, C. Torborg, K. Fumino, H. Junge, R. Ludwig and M. Beller, J. Am. Chem. Soc., 2010, 132, 8924-8934; (f) A. Boddien, F. Gärtner, D. Mellmann, P. Sponholz, H. Junge, G. Laurenczy and M. Beller, Chimia, 2011, 65, 214-218.

20 J. H. Shin, D. G. Churchill and G. Parkin, J. Organomet. Chem., 2002, 642, 9-15.

21 E. V. Kudrik, S. V. Makarov, E. S. Ageeva and I. A. Dereven'kov, Macroheterocycles, 2009, 2, 69-70.

22 T. W. Myers and L. A. Berben, Chem. Sci., 2014, 5, 2771-2777.

23 The only other Mo-containing compound that catalyzes the decarboxylation of formic acid contains Ru. See ref. $15 c$.

24 For other decomposition pathways of formic acid, see: $(a)$ P. Mars, J. J. F. Scholten and P. Zwietering, Adv. Catal., 1963, 14, 35-113; (b) Q. Luo, M. Beller and H. Jiao, J. Theor. Comput. Chem., 2013, 12, 1330001.

25 J. C. Fettinger, H.-B. Kraatz, R. Poli, E. A. Quadrelli and R. C. Torralba, Organometallics, 1998, 17, 5767-5775.

26 (a) M. Brookhart, K. Cox, F. G. N. Cloke, J. C. Green, M. L. H. Green and P. M. Hare, J. Chem. Soc., Dalton Trans., 1985, 423-433; (b) F. Abugideiri, M. A. Kelland and R. Poli, Organometallics, 1992, 11, 1303-1311.

27 H. G. Alt, H. E. Engelhardt, W. Kläui and A. Müller, J. Organomet. Chem., 1987, 331, 317-327.

28 P. Kalck, R. Pince, R. Poilblanc and J. Roussel, J. Organomet. Chem., 1970, 24, 445-452.

29 (a) R. B. King, in Organometallic Syntheses, Transition Metal Compounds, ed. J. J. Eisch and R. B. King, Academic Press, Inc.: New York, 1965, vol. 1, ch. H.1, pp. 156-158; (b) R. P. L. Burchell, P. Sirsch, A. Decken and G. S. McGrady, Dalton Trans., 2009, 30, 5851-5857; (c) E. O. Fischer, Inorg. Synth., 1963, 7, 136-139.

30 The formation of $\mathrm{CO}$ was not observed.

$31 \mathrm{CpMo}\left(\mathrm{PMe}_{3}\right)_{2}(\mathrm{CO}) \mathrm{H}$ TOF $=0.77 \mathrm{~h}^{-1} ; \mathrm{Cp} * \mathrm{Mo}\left(\mathrm{PMe}_{3}\right)_{2}(\mathrm{CO}) \mathrm{H}$, TOF $=1.8 \mathrm{~h}^{-1}$ (values at $50 \%$ conversion and room temperature).

32 Likewise, $\mathrm{Cp} * \mathrm{Mo}\left(\mathrm{PMe}_{3}\right)_{3} \mathrm{H}$ also converts to $\mathrm{Cp} * \mathrm{Mo}\left(\mathrm{PMe}_{3}\right)_{2}(\mathrm{CO}) \mathrm{H}$ in the presence of formic acid. See ref. 20 .

$33\left[\mathrm{CpMo}\left(\mathrm{PMe}_{3}\right)_{3} \mathrm{H}_{2}\right]\left[\mathrm{HCO}_{2}\right]$ is best isolated by performing the reaction in THF or pentane, rather than benzene.

34 For the structure of $\left[\mathrm{CpW}\left(\mathrm{PMe}_{3}\right)(\mathrm{CO})_{2} \mathrm{H}_{2}\right][\mathrm{OTf}]$, see: R. M. Bullock, J.-S. Song and D. J. Szalda, Organometallics, 1996, 15, 2504-2516.

35 It is worth noting that Poli has demonstrated that protonation of $\mathrm{Cp} * \mathrm{Mo}\left(\mathrm{PMe}_{3}\right)_{2}(\mathrm{CO}) \mathrm{H}$ by $\mathrm{HBF}_{4}$ yields a complex that exists as the dihydrogen compound, $\left[\mathrm{Cp} * \mathrm{Mo}\left(\mathrm{PMe}_{3}\right)_{2}(\mathrm{CO})\left(\eta^{2}-\mathrm{H}_{2}\right)\right]^{+}$, in THF and as the dihydride, $\left[\mathrm{Cp} * \mathrm{Mo}\left(\mathrm{PMe}_{3}\right)_{2}(\mathrm{CO}) \mathrm{H}_{2}\right]^{+}$, in $\mathrm{CH}_{2} \mathrm{Cl}_{2}$, both of which dissociate $\mathrm{H}_{2}$ at low temperature $(230 \mathrm{~K}){ }^{a}$ The former is characterized by a broad singlet at $\delta-5.14$ in the hydride region, while the latter is characterized by a triplet at $\delta$ $-3.92\left(J_{\mathrm{P}-\mathrm{H}}=55 \mathrm{~Hz}\right)$, which is comparable to that observed for $\left[\mathrm{CpMo}\left(\mathrm{PMe}_{3}\right)_{2}(\mathrm{CO}) \mathrm{H}_{2}\right]^{+}$. Bullock has also shown that protonation of $\mathrm{CpMo}(\mathrm{CO})(\mathrm{dppe}) \mathrm{H}$ by $\mathrm{TfOH}$ at low temperature generates a dihydride species [CpMo(CO)(dppe) $\left.\mathrm{H}_{2}\right][\mathrm{OTf}]$ which releases $\mathrm{H}_{2}$ to form $\mathrm{CpMo}(\mathrm{CO})(\mathrm{dppe})$ at room temperature. ${ }^{b}$ See: (a) P. A. Dub, N. V. Belkova, O. A. Filippov, J. C. Daran, L. M. Epstein, A. Lledos, E. S. Shubina and R. Poli, Chem. Eur. J., 2010, 16, 189-201; (b) T.-Y. Cheng, D. J. Szalda, J. Zhang and R. M. Bullock, Inorg. Chem., 2006, 45, 4712-4720.

36 Weak Brønsted acids bind to the carbonyl ligands of $\mathrm{Cp}^{*} \mathrm{Mo}\left(\mathrm{PMe}_{3}\right)_{2}(\mathrm{CO}) \mathrm{H}$, while strong Brønsted acids interact preferentially with the hydride ligand to yield a dihydrogen adduct. See: P. A. Dub, O. A. Filippov, N. V. Belkova, J.-C. Daran, L. M. Epstein, R. Poli and E. S. Shubina, Dalton Trans., 2010, 39, 2008-2015.

37 However, although decarboxylation of $\mathrm{CpMo}\left(\mathrm{PMe}_{3}\right)_{2}(\mathrm{CO})$ $\left(\kappa^{1}-\mathrm{O}_{2} \mathrm{CH}\right)$ is thermodynamically downhill, treatment of $\mathrm{CpMo}\left(\mathrm{PMe}_{3}\right)_{2}(\mathrm{CO}) \mathrm{H}$ with a high pressure of $\mathrm{CO}_{2}$ (59.9 atm) demonstrates that $\mathrm{CpMo}\left(\mathrm{PMe}_{3}\right)_{2}(\mathrm{CO})\left(\kappa^{1}-\mathrm{O}_{2} \mathrm{CH}\right)$ can be generated as a component of an equilibrium mixture $(K=$ $0.01 \mathrm{~atm}^{-1}$ ).

38 E. A. Quadrelli, H.-B. Kraatz and R. Poli, Inorg. Chem., 1996, 35, 5154-5162.

39 For protonation of $\mathrm{CpMo}\left(\mathrm{PPh}_{3}\right)(\mathrm{CO})_{2} \mathrm{H}$ with $\mathrm{TfOH}$, see: $(a)$ R. M. Bullock and J.-S. Song, J. Am. Chem. Soc., 1994, 116, 8602-8612; (b) K.-T. Smith, J. R. Norton and M. Tilset, Organometallics, 1996, 15, 4515-4520.

40 For other reports of $\mathrm{CpMo}(\mathrm{CO})_{3} \mathrm{OTf}$, see: (a) M. Appel, K. Schloter, J. Heidrich and W. Beck, J. Organomet. Chem., 1987, 322, 77-88; (b) E. Lindner, M. Henes, W. Wielandt, K. Eichele, M. Steimann, G. A. Luinstra and H.-H. Gortz, J. Organomet. Chem., 2003, 681, 12-23.

41 R. H. Morris, J. Am. Chem. Soc., 2014, 136, 1948-1959.

42 (a) E. J. Moore, J. M. Sullivan and J. R. Norton, J. Am. Chem. Soc., 1986, 108, 2257-2263; (b) G. Jia and R. H. Morris, J. Am. Chem. Soc., 1991, 113, 875-883.

43 G. A. Olah; A. Goeppert and G. K. S. Prakash, Beyond Oil and Gas: The Methanol Economy, Wiley-VCH, Weinheim, 2009.

44 For an early report of the heterogenous catalytic disproportionation of formic acid, see: P. Sabatier and A. Mailhe, Compt. Rend. Acad. Sci., 1911, 152, 1212-1215.

45 Selectivity for formation of methanol/methyl formate is defined as the percentage of formic acid used to produce methanol/methyl formate, based on the stoichiometry of the disproportionation reaction: $3 \times\left\{[\mathrm{MeOH}]_{\text {formed }}+\right.$ $\left.\left[\mathrm{HCO}_{2} \mathrm{Me}\right]_{\text {formed }}\right\} /\left\{\left[\mathrm{HCO}_{2} \mathrm{H}\right]_{\text {consumed }}-\left[\mathrm{HCO}_{2} \mathrm{Me}\right]_{\text {formed }}\right\} \times$ 100.

46 The selectivity of the ruthenium system may, however, be increased to $50 \%$ by addition of methane sulfonic acid. See ref. $15 \mathrm{~g}$.

47 S. Namorado, M. A. Antunes, L. F. Veiros, J. R. Ascenso, M. T. Duarte and A. M. Martins, Organometallics, 2008, 27, 4589-4599.

48 R. M. Bullock, Chem. Eur. J., 2004, 10, 2366-2374.

49 (a) R. M. Bullock and M. H. Voges, J. Am. Chem. Soc., 2000, 122, 12594-12595; (b) M. H. Voges and R. M. Bullock, J. Chem. Soc., Dalton Trans., 2002, 759-770; (c) 
B. F. M. Kimmich, P. J. Fagan, E. Hauptman, W. J. Marshall and R. M. Bullock, Organometallics, 2005, 24, 6220-6229; (d) J.-S. Song, D. J. Szalda, R. M. Bullock, C. J. C. Lawrie, M. A. Rodkin and J. R. Norton, Angew. Chem., Int. Ed., 1992, 31, 1233-1235; (e) M. A. Antunes, S. Namorado, C. G. de Azevedo, M. A. Lemos, M. T. Duarte, J. R. Ascenso and A. M. Martins, J. Organomet. Chem., 2010, 695, 13281336.

$50 K_{\text {ap }}=2.2 \times 10^{-7}$. See: $(a)$ T. C. Wehman and A. I. Popov, $J$. Phys. Chem., 1968, 72, 4031-4036; (b) S. Rondinini, P. Longhi, P. R. Mussini and T. Mussini, Pure Appl. Chem., 1987, 59, 1693-1702.

51 (a) C. Wakai, S. Morooka, N. Matubayasi and M. Nakahara, Chem. Lett., 2004, 33, 302-303; (b) S. Morooka, C. Wakai, N. Matubayasi and M. Nakahara, J. Phys. Chem. A, 2005, 109, 6610-6619; (c) S. Morooka, N. Matubayasi and M. Nakahara, J. Phys. Chem. A, 2007, 111, 2697-2705.

52 T. Y. Cheng, B. S. Brunschwig and R. M. Bullock, J. Am. Chem. Soc., 1998, 120, 13121-13137.

53 M. Horn, L. H. Schappele, G. Lang-Wittkowski, H. Mayr and A. R. Ofial, Chem. Eur. J., 2013, 19, 249-263.

54 W. W. Ellis, J. W. Raebiger, C. J. Curtis, J. W. Bruno and D. L. DuBois, J. Am. Chem. Soc., 2004, 126, 2738-2743.

55 W. W. Ellis, R. Ciancanelli, S. M. Miller, J. W. Raebiger, M. Rakowski DuBois and D. L. DuBois, J. Am. Chem. Soc., 2003, 125, 12230-12236.

56 (a) J. Ito and H. Nishiyama, Tetrahedron Lett., 2014, 55, 31333146; (b) S. Gladiali and E. Alberico, Chem. Soc. Rev., 2006, 35, 226-236; (c) S. Gladiali and E. Alberico, in Transition Metals for Organic Synthesis, ed. M. Beller and C. Bolm, Wiley-VCH, Weinheim, 2nd edn, 2004, vol. 2, pp. 145-166; (d) R. Malacea, R. Poli and E. Manoury, Coord. Chem. Rev., 2010, 254, 729-752; (e) R. H. Morris, Chem. Soc. Rev., 2009, 38, 2282-2291; (f) J. S. M. Samec, J.-E. Bäckvall, P. G. Andersson and P. Brandt, Chem. Soc. Rev., 2006, 35, 237-248; (g) R. Noyori and S. Hashiguchi, Acc. Chem. Res., 1997, 30, 97-102.

57 (a) R. A. W. Johnstone, A. H. Wilby and I. D. Entwistle, Chem. Rev., 1985, 85, 129-170; (b) S. Rajagopal, M. K. Anwer and A. F. Spatola, in Peptides: Design, Synthesis, and Biological Activity, Birkhäuser, Boston, 1994, pp. 11-26; (c) B. Štefane and F. Požgan, Catal. Rev., 2014, 56, 82-174; (d) Z. Shen, Y. Zhang, F. Jin, X. Zhou, A. Kishita and K. Tohji, Ind. Eng. Chem. Res., 2010, 49, 6255-6259.

58 J. E. Logsdon and R. A. Loke, Isopropyl alcohol, Kirk-Othmer Encycl. Chem. Technol., 2000, DOI: 10.1002/ 0471238961.0919151612150719.a01.

59 (a) J. Václavík, P. Sot, B. Vilhanová, J. Pecháček, M. Kuzma and P. Kačer, Molecules, 2013, 18, 6804-6828; (b) X. Wu,
C. Wang and J. Xiao, Platinum Met. Rev., 2010, 54, 3-19; (c) A. Robertson, T. Matsumoto and S. Ogo, Dalton Trans., 2011, 40, 10304-10310; (d) A. Fujii, S. Hashiguchi, N. Uematsu, T. Ikariya and R. Noyori, J. Am. Chem. Soc., 1996, 118, 2521-2522; (e) C.-Y. Huang, K.-Y. Kuan, Y.-H. Liu, S.-M. Peng and S.-T. Liu, Organometallics, 2014, 33, 2831-2836; (f) V. Fábos, L. T. Mika and I. T. Horváth, Organometallics, 2014, 33, 181-187; $(g)$ T. Thananatthanachon and T. B. Rauchfuss, ChemSusChem, 2010, 3, 1139-1141; (h) D. S. Matharu, D. J. Morris, G. J. Clarkson and M. Wills, Chem. Commun., 2006, 3232-3234; (i) Y. Himeda, N. Onozawa-Komatsuzaki, H. Sugihara, H. Arakawa and K. Kasuga, J. Mol. Catal. A: Chem., 2003, 195, 95-100; (j) T. Mizugaki, Y. Kanayama, K. Ebitani and K. Kaneda, J. Org. Chem., 1998, 63, 23782381; (k) A. Fujii, S. Hashiguchi, N. Uematsu, T. Ikariya and R. Noyori, J. Am. Chem. Soc., 1996, 118, 2521-2522; (l) Y. Watanabe, T. Ohta and Y. Tsuji, Bull. Chem. Soc. Jpn., 1982, 55, 2441-2444; (m) C. A. Mebi, R. P. Nair and B. J. Frost, Organometallics, 2007, 26, 429-438; (n) S. Bolano, L. Gonsalvi, F. Zanobini, F. Vizza, V. Bertolasi, A. Romerosa and M. Peruzzini, J. Mol. Catal. A: Chem., 2004, 224, 61-70.

60 J. Yu and J. B. Spencer, Chem. Eur. J., 1999, 5, 2237-2240.

61 A. Nova, D. J. Taylor, A. J. Blacker, S. B. Duckett, R. N. Perutz and O. Eisenstein, Organometallics, 2014, 33, 3433-3442.

62 See for example: (a) T. Nakano, J. Ando, Y. Ishii and M. Ogawa, Technol. Rep. Kansai Univ., 1987, 29, 69-76; (b) G. Wienhöfer, F. A. Westerhaus, R. V. Jagadeesh, K. Junge, H. Junge and M. Beller, Chem. Commun., 2012, 48, 48274829; (c) G. Wienhöfer, I. Sorribes, A. Boddien, F. Westerhaus, K. Junge, H. Junge, R. Llusar and M. Beller, J. Am. Chem. Soc., 2011, 133, 12875-12879.

63 It is pertinent to note that compounds of this class have been used as catalysts for ionic hydrogenation employing $\mathrm{H}_{2}$. See, for example, ref. 48.

64 Selectivities are the average of two runs.

65 Selectivity for transfer hydrogenation is defined as $\left\{[\mathrm{ROH}]_{\text {formed }}+\left[\mathrm{HCO}_{2} \mathrm{R}\right]_{\text {formed }}\right\} /\left\{\left[\mathrm{HCO}_{2} \mathrm{H}\right]_{\text {consumed }}-\right.$ $\left.\left[\mathrm{HCO}_{2} \mathrm{R}\right]_{\text {formed }}-\left[\mathrm{HCO}_{2} \mathrm{Me}\right]_{\text {formed }}\right\} \times 100$.

66 Formate esters have also been observed in other systems. See, for example, ref. $59 l$ and $62 a$.

67 Note that it is more difficult to reduce esters by ionic hydrogenation than it is to reduce aldehydes and ketones by ionic hydrogenation. See, for example: J. S. Song, D. J. Szalda and R. M. Bullock, Organometallics, 2001, 20, 3337-3346. 